\title{
Isotherms and thermodynamic properties of water adsorption in 'Cumari-do-Pará' pepper seeds
}

\author{
Karen C. Rodrigues ${ }^{1}$, Hellismar W. da Silva², Isneider L. Silva ${ }^{3}$, Samuel G. F. dos Santos ${ }^{1}$, \\ Daniel P. da Silva ${ }^{1} \&$ Renato S. Rodovalho ${ }^{4}$
}

1 Instituto Federal de Educação, Ciência e Tecnologia Goiano/Campus Ceres, Ceres, GO, Brasil. E-mail: karencamposrodrigues@hotmail.com - ORCID: 0000-0002-9409-4524; samuel-2100@hotmail.com - ORCID: 0000-0003-1618-6877; danielsilva.agron@gmail.com - ORCID: 0000-0002-7217-2886

${ }^{2}$ Universidade Federal de Lavras/Departamento de Agricultura, Lavras, MG, Brasil. E-mail: waksonhellismar@gmail.com (Corresponding author) ORCID: 0000-0002-1353-2247

${ }^{3}$ Universidade Estadual de Goiás, Anápolis, GO, Brasil. E-mail: isneider.luiz@gmail.com - ORCID: 0000-0002-0609-3274

${ }^{4}$ Instituto Federal de Educação, Ciência e Tecnologia Goiano/Campus Ceres/Curso de Bacharelado em Agronomia, Ceres, GO, Brasil. E-mail: souzarodovalho@gmail.com - ORCID: 0000-0002-0558-4098

\begin{abstract}
Studies related to water sorption in seeds are essential for the design and optimization of storage systems. The objective of this research was to determine and model the adsorption isotherms and calculate the latent heat of water vaporization, differential enthalpy and entropy, the isokinetic theory and Gibbs free energy for 'Cumari-do-Pará' pepper seeds. The equilibrium moisture contents were obtained by the static gravimetric method at temperatures of 30,35 and $40^{\circ} \mathrm{C}$ and water activities between 0.290 and 0.900 (decimal). The Chen-Clayton model is the one that best represents the water adsorption isotherms in 'Cumari-do-Pará' pepper seeds under the studied conditions, with $9.94 \%$ mean relative error, 0.40 mean estimated error and random distribution of residuals. The latent heat of vaporization ranged from 2,555.669 to $3,162.180 \mathrm{~kJ} \mathrm{~kg}^{-1}$. The enthalpy, entropy and Gibbs free energy increase with the reduction in the equilibrium moisture content of the seeds. The isokinetic theory is valid for the adsorption process.
\end{abstract}

Key words: Capsicum chinense L., hygroscopicity, latent heat, isokinetic

\section{Isotermas e propriedades termodinâmicas de adsorção de água em sementes de pimenta Cumari-do-Pará}

RESUMO: Estudos relacionados com a sorção de água em sementes são essenciais para o dimensionamento e otimização de sistemas de armazenagem. Assim, objetivou-se determinar e modelar as isotermas de adsorção e calcular o calor latente de vaporização da água, a entalpia e entropia diferencial, a teoria isocinética e a energia livre de Gibbs para as sementes de pimenta Cumari-do-Pará. Os teores de água de equilíbrio foram obtidos pelo método estático gravimétrico nas temperaturas de 30,35 e $40{ }^{\circ} \mathrm{C}$ e atividades de água entre 0,290 a 0,900 (decimal). O modelo de Chen-Clayton é o que melhor representa as isotermas de adsorção de água em sementes de pimenta Cumari-do-Pará nas condições estudadas, apresentando 9,94\% de erro médio relativo, 0,40 de erro médio estimado e distribuição aleatória dos resíduos. O calor latente de vaporização variou de $2.555,669$ a $3.162,180 \mathrm{~kJ} \mathrm{~kg}^{-1}$. A entalpia, a entropia e a energia livre de Gibbs aumentam com a redução do teor de água de equilíbrio das sementes. A teoria isocinética é válida para o processo de adsorção.

Palavras-chave: Capsicum chinense L., higroscopicidade, calor latente, isocinética 


\section{INTRODUCTION}

Capsicum chinense $\mathrm{L}$. peppers are the most cultivated and consumed in Brazil. This species is part of the Brazilian popular culture and has the Amazon Basin as its center of domestication (Carvalho et al., 2014; Baba et al., 2015).

For being widely cultivated in Brazil, adequate drying and storage procedures are necessary for conserving the quality of pepper seeds, considering that they are extracted with high moisture contents (Silva et al., 2015b; Silva et al., 2016). For these operations to be carried out properly, it is necessary to know the relationship between the equilibrium moisture content and relative air humidity at a specific temperature (Corrêa et al., 2015). This relationship is known as sorption isotherms and can be represented by mathematical equations (Goneli et al., 2016b).

Sorption isotherms are used to define product dehydration limits, estimate changes in moisture content, and avoid the activity of microorganisms during storage (Corrêa et al., 2015; Silva et al., 2015b). In addition, sorption isotherms provide information on water sorption mechanisms with the constituents of the product (Corrêa et al., 2015).

From the isotherms it is possible to determine the latent heat of vaporization, enthalpy, entropy, isokinetic theory and Gibbs free energy (Ferreira et al., 2011; Sousa et al., 2015; Goneli et al., 2016a; Silva \& Rodovalho, 2016). These thermodynamic parameters provide information that enables the calculation of energy in heating and mass transfer in biological systems, thus enabling greater understanding of the properties of water molecules (Goneli et al., 2016a).

In view of the above, the objective of this study was to determine and model the isotherms and calculate the thermodynamic properties of water adsorption in 'Cumarido-Pará pepper seeds.

\section{Material ANd Methods}

The experiment was conducted at the Laboratório de Alimentos of the Instituto Federal Goiano - Campus of Ceres, GO, Brazil. Pepper fruits of the 'Cumari-do-Pará' variety were harvested at full maturity and the seeds were extracted manually and dried in a drying oven at $70{ }^{\circ} \mathrm{C}$ for $48 \mathrm{~h}$ until reaching moisture content of 3\% (d.b.) (Goneli et al., 2010).

The equilibrium moisture contents were determined at temperatures of 30,35 and $40{ }^{\circ} \mathrm{C}$ and water activity $\left(\mathrm{a}_{\mathrm{w}}\right)$ within the range from 0.290 to 0.900 (decimal) by the static gravimetric method. In this method, the seeds are placed in airtight glass containers, containing three replicates for each water activity $\left(\mathrm{a}_{\mathrm{w}}\right)$, according to the methodology described by Silva \& Rodovalho (2016).

Mathematical models frequently used to represent isotherms of different seeds were fitted to the experimental data (Corrêa et al., 2015; 2016; Silva et al., 2015b; Zeymer et al., 2017), whose expressions are presented in Table 1.

The mathematical models were fitted by nonlinear regression analysis using the Gauss-Newton method. The degree of fit was verified by the magnitude of the coefficient of determination $\left(R^{2}\right)$, mean relative error $(P)$, mean estimated
Table 1. Mathematical models used to represent the sorption isotherms

\begin{tabular}{|c|c|c|}
\hline Model designation & Model & \\
\hline$X e=\left[-1 /\left(c T^{d}\right)\right] \ln \left[\ln \left(a_{w}\right) /\left(-a T^{b}\right)\right]$ & Chen-Clayton & (1) \\
\hline$X e=a-b \ln \left[-(T+c) \ln \left(a_{w}\right)\right]$ & Chung-Pfost & (2) \\
\hline$X e=(-1 / b) \ln \left[(T+c) \ln \left(a_{w}\right) /(-a)\right]$ & Modified Chung-Pfost & (3) \\
\hline$X e=(a+b T) /\left[a_{w} /\left(1-a_{w}\right)\right]^{1 / c}$ & Modified Oswin & (4) \\
\hline$X e=a-(b T)-c \ln \left(1-a_{w}\right)$ & Smith & (5) \\
\hline
\end{tabular}

error (SE) and trend of residual distribution (Rodovalho et al., 2015; Corrêa et al., 2016; Goneli et al., 2016b). P and SE were calculated using the following expressions:

$$
\begin{aligned}
& P=\frac{100}{n} \sum_{i=1}^{n}\left(\frac{|Y-\hat{Y}|}{Y}\right) \\
& S E=\sqrt{\frac{\sum_{i=1}^{n}(Y-\hat{Y})^{2}}{D F}}
\end{aligned}
$$

where:

$\mathrm{Y}$ - experimental value;

$\hat{Y} \quad$ - value estimated by model;

$\mathrm{n}$ - number of experimental observations; and,

DF - degrees of freedom of the residual.

The Clausius-Clapeyron equation (Eq. 8) was used to calculate the L L'-1 ratio, whose data were fitted with the Rodrigues-Arias equation (Eq. 9), and then the latent heat of vaporization of the water in the seeds (Eq. 10) for each temperature and moisture content studied (Corrêa et al., 1998).

$$
\begin{gathered}
\operatorname{Ln}(\mathrm{Pv})=\frac{\mathrm{L}}{\mathrm{L}^{\prime}} \operatorname{Ln}(\mathrm{Pvs})+\mathrm{C} \\
\frac{\mathrm{L}}{\mathrm{L}^{\prime}}-1=\mathrm{a} \exp \left(-\mathrm{b} \mathrm{Xe} \mathrm{m}^{\mathrm{m}}\right) \\
\mathrm{L}=(2502.2-2.39 \mathrm{~T})\left[1+\mathrm{a} \exp \left(-\mathrm{b} \mathrm{Xe} \mathrm{e}^{\mathrm{m}}\right)\right]
\end{gathered}
$$

where:

$\mathrm{Pv}$ - vapor pressure of free water, for a certain equilibrium temperature $\mathrm{T}, \mathrm{kPa}$;

Pvs - saturation vapor pressure of free water, for a certain equilibrium temperature $(\mathrm{T}), \mathrm{kPa}$;

L - latent heat of vaporization of the water in the product, $\mathrm{kJ} \mathrm{kg}^{-1}$;

L' - latent heat of vaporization of free water, at the equilibrium temperature, $\mathrm{kJ} \mathrm{kg}^{-1}$;

C - integration constant; and,

$\mathrm{a}, \mathrm{b}, \mathrm{m}$ - coefficients that depend on the product.

Differential enthalpy, differential entropy, isokinetic theory and Gibbs free energy of adsorption were calculated using the 
methodology described by Corrêa et al. (2012), according to the following expressions:

$$
\begin{gathered}
\ln \left(\mathrm{a}_{\mathrm{w}}\right)=\frac{\Delta \mathrm{h}_{\mathrm{st}}}{\mathrm{RT}}-\frac{\Delta \mathrm{S}}{\mathrm{R}} \\
\Delta \mathrm{S}=\frac{\Delta \mathrm{h}_{\mathrm{st}}-\Delta \mathrm{G}}{\mathrm{T}_{\mathrm{a}}} \\
\Delta \mathrm{h}_{\mathrm{st}}=\mathrm{T}_{\mathrm{B}}(\Delta \mathrm{S})+\Delta \mathrm{G}_{\mathrm{B}} \\
\Delta \mathrm{G}=\mathrm{R} \mathrm{T}_{\mathrm{a}} \ln \left(\mathrm{a}_{\mathrm{w}}\right) \\
\mathrm{T}_{\mathrm{hm}}=\frac{\mathrm{n}}{\sum\left(\frac{1}{\mathrm{~T}}\right)} \\
\mathrm{T}_{\mathrm{B}}=\hat{\mathrm{T}}_{\mathrm{B}} \pm \mathrm{t}_{\mathrm{m}-2, \alpha / 2 \sqrt{\operatorname{Var}\left(\mathrm{T}_{\mathrm{B}}\right)}}
\end{gathered}
$$

where:

$a_{w} \quad$ - water activity, decimal;

$\Delta \mathrm{h}_{\mathrm{st}}$ - differential enthalpy of sorption, $\mathrm{kJ} \mathrm{kg}^{-1}$;

$\Delta \mathrm{S}$ - differential entropy of sorption, $\mathrm{kJ} \mathrm{kg}^{-1} \mathrm{~K}^{-1}$;

$\mathrm{R}$ - universal gas constant $\left(8.314 \mathrm{~kJ} \mathrm{kmol}^{-1} \mathrm{~K}^{-1}\right)$, equal to $0.4619 \mathrm{~kJ} \mathrm{~kg}^{-1} \mathrm{~K}^{-1}$ for water vapor;

$\mathrm{T}_{\mathrm{a}} \quad$ - absolute temperature $(\mathrm{K})$;

$\Delta \mathrm{G}$ - Gibbs free energy, $\mathrm{kJ} \mathrm{kg}^{-1}$;

$\mathrm{T}_{\mathrm{B}} \quad$ - isokinetic temperature, $\mathrm{K}$;

$\Delta \mathrm{G}_{\mathrm{B}}$ - Gibbs free energy at isokinetic temperature, $\mathrm{kJ} \mathrm{kg}^{-1}$;

$\mathrm{T}_{\mathrm{hm}}$ - harmonic mean temperature, $\mathrm{K}$;

$\mathrm{n}$ - number of temperatures used; and,

$\mathrm{m}$ - number of enthalpy-entropy data pairs.

\section{Results AND Discussion}

The models fitted to the hygroscopic equilibrium moisture contents of 'Cumari-do-Pará' seeds had coefficients of determination above 0.96 (Table 2). The single use of this parameter is not sufficient to characterize adequate fit of nonlinear models (Corrêa et al., 2015), so it is necessary to perform an improved analysis with other statistical indices (Zeymer et al., 2017).

The fitting of mathematical models to a physical process is inversely proportional to the mean relative error (Draper \& Smith, 1998), whose values must be less than 10\% (Ferreira et al., 2011; Rodovalho et al., 2015). Thus, it can be observed that among the models studied, only Chen-Clayton had P less than $10 \%$ (Table 2). This model also showed the lowest mean estimated error $(\mathrm{SE}=0.4045)$ and random distribution of residuals, thus showing the best fit to the experimental data.

The Chen-Clayton model was perfected from the Henderson model by adding a new parameter to the equation, which was derived from the potential theory associated with the simplified equations of the thermodynamic states. After the addition of a new parameter, the Chen-Clayton model was widely used to describe the hygroscopic behavior of various agricultural products, such as seeds and grains (Henderson, 1952; Thompson et al., 1968; Chen \& Clayton, 1971; Ribeiro et al., 2005).

For showing the best statistical indices, the Chen-Clayton model was selected to represent the adsorption isotherms of 'Cumari-do-Pará pepper for temperatures of 30, 35 and 40 ${ }^{\circ} \mathrm{C}$ and water activity within the range from 0.290 to 0.900 (decimal) (Figure 1). This model also showed adequate fit to the data of 'Cabacinha' (C. chinense L.) pepper seeds for temperatures of $10,20,30$ and $40^{\circ} \mathrm{C}$ and water activity between 0.213 and 0.975 (decimal) (Silva et al., 2015b).

The adsorption isotherms of 'Cumari-do-Pará pepper seeds estimated by the Chen-Clayton model have a sigmoidal shape, characteristic of type II curves (Brunauer et al., 1938), considered standard for most agricultural products, such as seeds of cucumber (Corrêa et al., 2015), beetroot (Corrêa et al., 2016) and pepper (Capsicum sp.) (Ferreira et al., 2011; Rodovalho et al., 2015; Silva et al., 2015b; Silva \& Rodovalho, 2016).

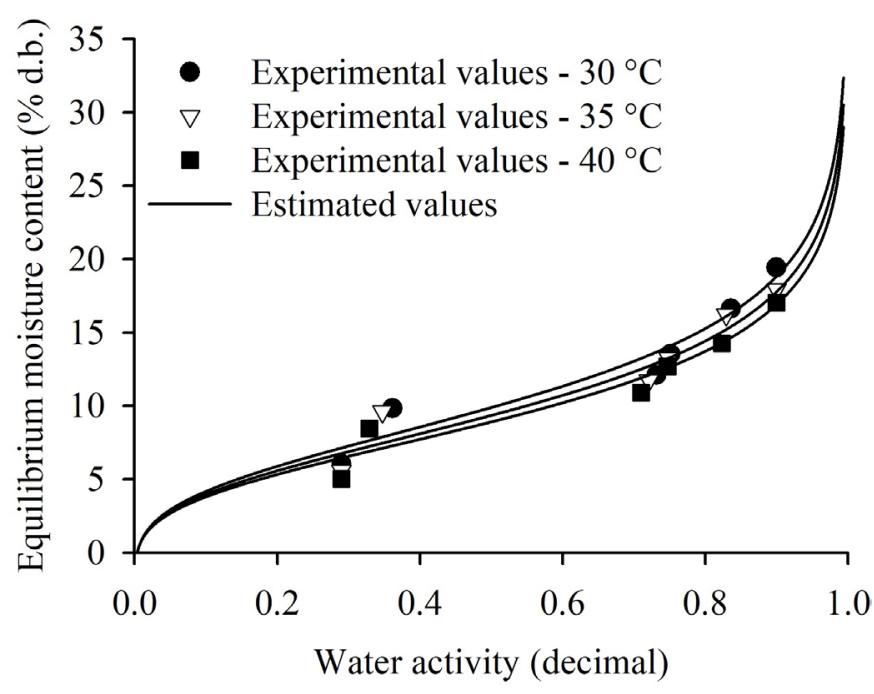

\begin{tabular}{|c|c|c|c|c|c|c|c|c|}
\hline \multirow{2}{*}{ Models } & \multirow{2}{*}{$\mathbf{R}^{2}$} & \multirow{2}{*}{$\begin{array}{c}P \\
(\%)\end{array}$} & \multirow{2}{*}{$\begin{array}{c}\text { SE } \\
\text { (decimal) }\end{array}$} & \multirow{2}{*}{ RD } & \multicolumn{4}{|c|}{ Parameters } \\
\hline & & & & & $\mathbf{a}$ & b & C & d \\
\hline Chen-Clayton & 0.9646 & 9.9368 & 0.4045 & RN & 4.6202 & 0.0536 & 0.0562 & 0.3883 \\
\hline Chung-Pfost & 0.9637 & 10.0878 & 0.4730 & RN & 23.6614 & 4.4935 & -0.1321 & - \\
\hline Modified Chung-Pfost & 0.9637 & 10.0878 & 0.4730 & RN & 193.5895 & 0.2225 & -0.1312 & - \\
\hline Modified Oswin & 0.9669 & 10.0221 & 0.4520 & RN & 12.7664 & -0.1006 & 3.2190 & - \\
\hline Smith & 0.9648 & 10.2602 & 0.4658 & RN & 9.7339 & 0.1326 & 5.7179 & - \\
\hline
\end{tabular}

Figure 1. Experimental values of equilibrium moisture content and adsorption isotherms estimated by the Chen-Clayton model for 'Cumari-do-Pará' pepper seeds

Table 2. Coefficients of determination $\left(\mathrm{R}^{2}\right)$, mean relative error $(\mathrm{P})$, mean estimated error $(\mathrm{SE})$, residual distribution $(\mathrm{RD})$ and parameters for models fitted to adsorption isotherms of 'Cumari-do-Pará' pepper seeds

RN - Random distribution 
For the same water activity, the increase in temperature reduced the equilibrium moisture content of 'Cumari-do-Pará' pepper seeds, and this same behavior is observed with the reduction of water activity for the same temperature (Figure 1). It is known that this behavior occurs due to the difference in water vapor pressure between the product and the surrounding air (Silva et al., 2015b). Thus, the increase in temperature reduces the water vapor pressure in the air at a same water activity and, consequently, the equilibrium moisture content of 'Cumari-do-Pará pepper seeds.

The $\mathrm{L} \mathrm{L}^{-1}$ ratio showed values greater than 1 for the entire range of equilibrium moisture content studied (Figure 2A), evidencing that the energy released by the seeds during the adsorption process is always greater than the latent heat of vaporization of free water $\left(\mathrm{L}^{\prime}=2,418.550 \mathrm{~kJ} \mathrm{~kg}^{-1}\right)$.

For temperatures of 30,35 and $40{ }^{\circ} \mathrm{C}$ and equilibrium moisture content within the range from 8.46 to $19.41 \%$ (d.b.), the latent heat of vaporization ranged from 3,162.180 to $2,555.669 \mathrm{~kJ} \mathrm{~kg}^{-1}$ (Figure 2B). It can be noted that this thermodynamic variable increased with the reduction in the equilibrium moisture content of 'Cumari-do-Pará' pepper seeds and with the increase in temperature. Lower values of latent heat of vaporization for the highest moisture contents characterize the existence of free water molecules (Silva \& Rodovalho, 2016), that is, it indicates the presence of water in the condition of solvent, which forms weak intermolecular bonds when compared to water from chemisorption at reduced

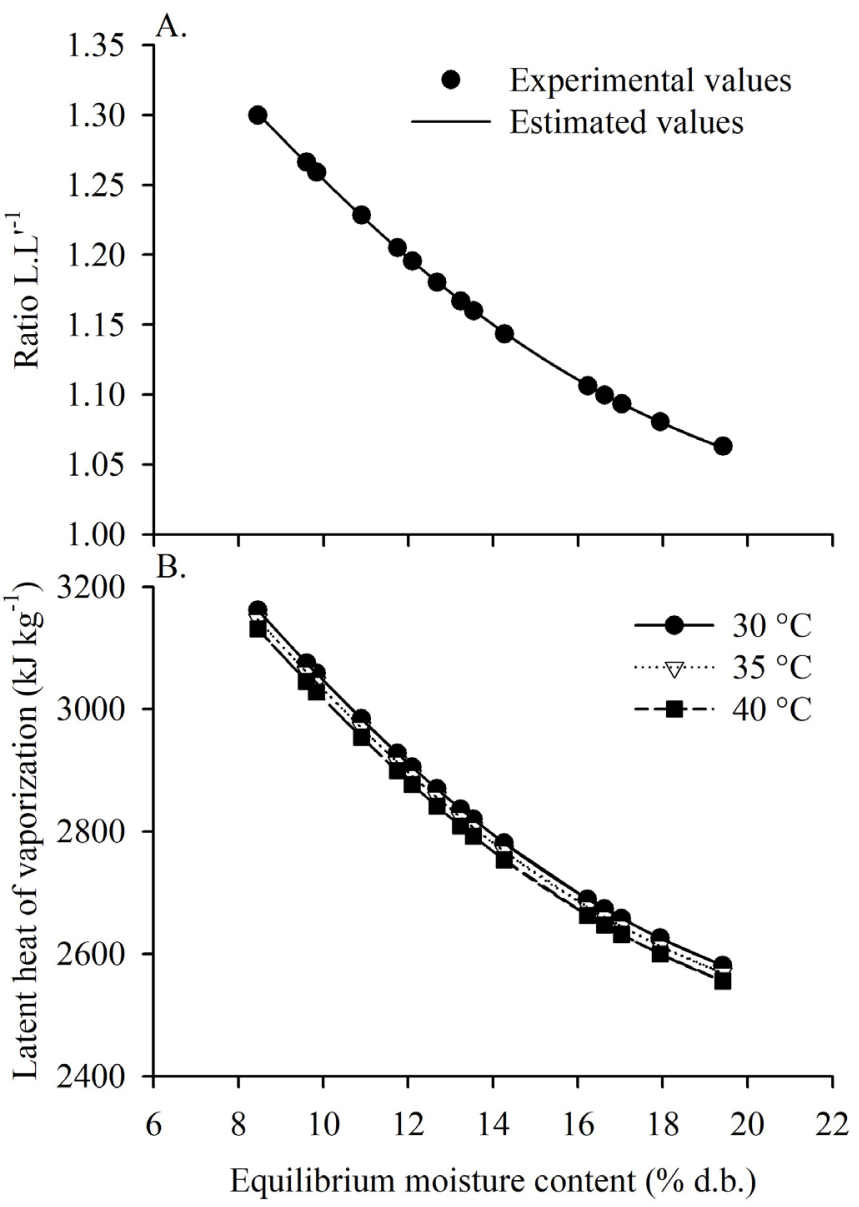

Figure 2. $\mathrm{L} \mathrm{L}^{\mathrm{\prime}-1}$ ratio $(\mathrm{A})$ and latent heat of vaporization of adsorption (B) as a function of the equilibrium moisture content of 'Cumari-do-Pará' pepper seeds moisture contents. Thus, water as a solvent needs less energy to be removed when compared to water from chemisorption (Rockland \& Stewart, 1981).

The differential enthalpy (Figure 3A) and differential entropy (Figure 3B) of adsorption increased with the reduction in the equilibrium moisture content of 'Cumari-do-Pará' pepper seeds. For the equilibrium moisture content range from 8.46 to $19.41 \%$ (d.b.), these thermodynamic variables ranged from 726.745 to $152.841 \mathrm{~kJ} \mathrm{~kg}^{-1}$ and from 1.966 to $0.461 \mathrm{~kJ} \mathrm{~kg}^{-1}$ $\mathrm{K}^{-1}$, respectively.

Enthalpy has been related to the bonding force between water molecules and the adsorbent surface of the product (Goneli et al., 2016a). On the other hand, entropy is related to the number of active sorption sites available at a specific
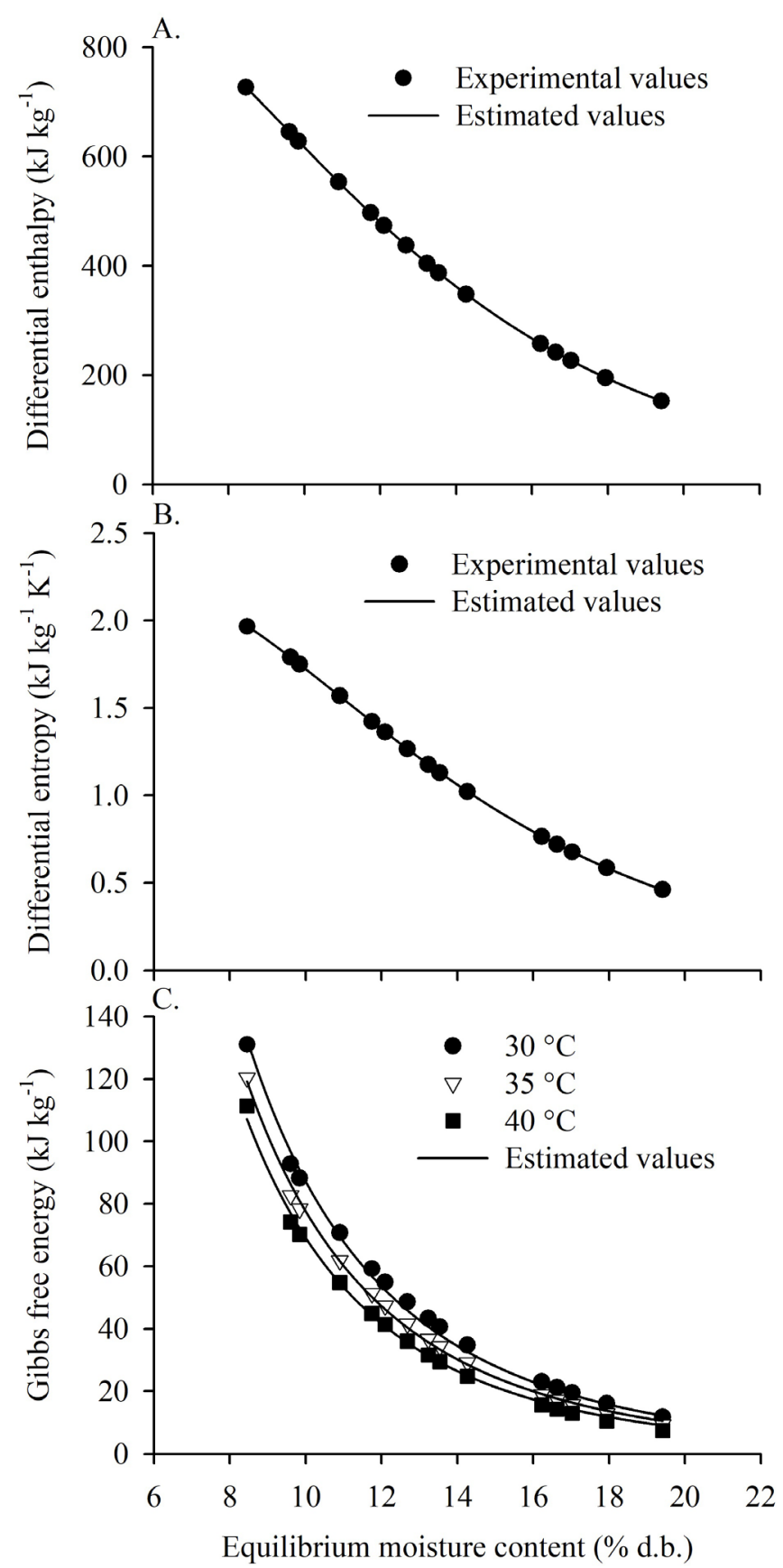

Figure 3. Enthalpy (A), entropy (B) and Gibbs free energy (C) of adsorption as a function of the equilibrium moisture content in 'Cumari-do-Pará' pepper seeds 
energy level (Silva et al., 2015a). Thus, the high values of differential enthalpy and entropy for the lower equilibrium moisture contents show greater bonding force of water molecules with the sorption sites of 'Cumari-do-Pará' pepper seeds, as well as a greater number of active sites available for sorption (Figure 3). This trend has also been observed for seeds of cucumber (Corrêa et al., 2015) and 'Cabacinha' pepper (Silva et al., 2016).

The relationship between the values of differential enthalpy and entropy showed a high coefficient of determination $\left(\mathrm{R}^{2}=0.9991\right)$, indicating the existence of isokinetic theory for the adsorption process in 'Cumari-do-Pará pepper seeds. To validate the existence of this phenomenon, Krug et al. (1976a,b) established that the isokinetic temperature $\left(\mathrm{T}_{\mathrm{B}}\right)$ should be different from the harmonic mean temperature $\left(\mathrm{T}_{\mathrm{hm}}\right)$. Thus, the isokinetic temperature obtained was $375.581 \pm 17.676 \mathrm{~K}$, being higher than the harmonic mean temperature (307.671 $\mathrm{K}$ ), hence confirming the phenomenon of isokinetic theory for the adsorption process.

Isokinetic temperature has been used to characterize the temperature at which the product is in equilibrium (Goneli et al., 2016a). According to Leffler (1955), if $T_{B}>T_{h m}$ the sorption process is controlled by enthalpy; otherwise, if $\mathrm{T}_{\mathrm{B}}<\mathrm{T}_{\mathrm{hm}}$, the process is controlled by entropy. Thus, the process of adsorption of 'Cumari-do-Pará pepper seeds is controlled by enthalpy, following the same behavior as those observed in various agricultural products (Corrêa et al., 2015; Sousa et al., 2015; Goneli et al., 2016a; Silva et al., 2016).

Gibbs free energy increases with the reduction in moisture content and decreases with the increase in temperature (Figure 3C). It is known that this thermodynamic variable is related to the work necessary to make the sorption sites available (Corrêa et al., 2015). Positive values for Gibbs free energy characterize an endothermal reaction (Goneli et al., 2016a; Silva et al., 2016), i.e., the one which requires energy for water sorption to occur (Sousa et al., 2015). Therefore, the reduction in the equilibrium moisture content of 'Cumari-do-Pará pepper seeds increased the need for energy for adsorption to occur, so this is a nonspontaneous process.

The regression equations fitted to the $\mathrm{L} \mathrm{L}^{-1}$ ratio, differential enthalpy, differential entropy and Gibbs free energy of adsorption showed high degree of fit to the experimental data $\left(\mathrm{R}^{2}>0.99\right)$ (Table 3$)$. Therefore, these equations can be used to estimate these thermodynamic variables for the adsorption process of 'Cumari-do-Pará pepper seeds for the equilibrium moisture content range from 8.46 to $19.41 \%$ (d.b.) and temperatures of 30,35 and $40^{\circ} \mathrm{C}$.

Table 3. Regression equations and coefficients of determination for the $L L^{-1}$ ratio, enthalpy $\left(\Delta \mathrm{h}_{\mathrm{st}}\right)$, entropy $(\Delta S)$ and Gibbs free energy $(\Delta G)$ of adsorption as a function of the equilibrium moisture content of 'Cumari-do-Pará' pepper seeds

\begin{tabular}{|c|c|}
\hline Regression equation & $R^{2}$ \\
\hline $\mathrm{LL}^{\prime-1}=1+0.5140^{* \star} \exp \left(-0.0156^{* *} X \mathrm{e}^{1.6544^{* *}}\right)$ & 0.9999 \\
\hline$\Delta h_{\mathrm{st}}=465.3714^{\star \star} \exp \left(-0.2262^{\star \star} \mathrm{Xe}\right)\left(\mathrm{X} \mathrm{e}^{1.1049^{\star \star}}\right)$ & 0.9999 \\
\hline$\Delta S=0.7309^{* *} \exp \left(-0.2401^{* *} \mathrm{Xe}\right)\left(\mathrm{Xe}^{1.4151^{* *}}\right)$ & 0.9999 \\
\hline$\Delta G=9796.3510^{\text {ns }} \exp \left(-0.0937^{\text {ns }} \mathrm{Xe}\right)\left[\mathrm{Xe}^{\left(-0.0101^{* *} \mathrm{~T}-1.3411^{* *}\right)}\right]$ & 0.9984 \\
\hline
\end{tabular}

"Significant by t-test $(\mathrm{p}<0.01) .{ }^{\text {ns }}$ Not significant

\section{Conclusions}

1. The Chen-Clayton model is the one that best represents the adsorption isotherms of 'Cumari-do-Pará pepper seeds at temperatures of 30,35 and $40^{\circ} \mathrm{C}$ and water activity within the range from 0.290 to 0.900 (decimal).

2. The latent heat of vaporization, differential enthalpy, differential entropy and Gibbs free energy increase with the reduction in the equilibrium moisture content of 'Cumari-doPará pepper seeds.

3. The enthalpy-entropy compensation phenomenon is valid for the process of adsorption of 'Cumari-do-Parä pepper seeds, which is controlled by enthalpy.

\section{ACKNOWLeDgments}

This research was supported by Instituto Federal Goiano (Campus Ceres), Fundação de Amparo à Pesquisa do Estado de Goiás (FAPEG) and Conselho Nacional de Desenvolvimento Científico e Tecnológico (CNPq).

\section{Literature Cited}

Baba, V. Y.; Rocha, K. R.; Gomes, G. P.; Ruas, C. de F.; Ruas, P. M.; Rodrigues, R.; Gonçalves, L. S. A. Genetic diversity of Capsicum chinense accessions based on fruit morphological characterization and AFLP markers. Genetic Resources and Crop Evolution, v.40, p.1-11, 2015.

Brunauer, S.; Emmett, P. H.; Teller, E. Adsorption of gases in multimolecular layer. Journal of American Chemistry Society, v.60, p.309-319, 1938. https://doi.org/10.1021/ja01269a023

Carvalho, S. I. C.; Ragassi, C. F.; Bianchetti, L. B.; Reifschneider, F. J. B.; Buso, G. S. C.; Faleiro, F. G. Morphological and genetic relationships between wild and domesticated forms of peppers (Capsicum frutescens L. and C. chinense Jacquin). Genetics and Molecular Research, v.13, p.7447-7464, 2014. https://doi. org/10.4238/2014.September.12.11

Chen, C. S.; Clayton, J. T. The effort of temperature on sorption isotherms of biological materials. Transactions of the American Society of Agricultural Engineering, v.14, p.927-929, 1971. https:// doi.org/10.13031/2013.38422

Corrêa, P. C.; Christ, D.; Martins, J. H.; Mantovani, B. H. M. Curvas de dessorção e calor latente de vaporização para as sementes de milho pipoca (Zea mays). Revista Brasileira de Engenharia Agrícola e Ambiental, v.2, p.75-79, 1998. https://doi.org/10.1590/1807-1929/ agriambi.v2n1p75-79

Corrêa, P. C.; Oliveira, G. H. H. de; Oliveira, A. P. L. R. de; Goneli, A. L. D.; Botelho, F. M. Isotermas de dessorção de sementes de beterraba. Engenharia na Agricultura, v.24, p.15-21, 2016. https:// doi.org/10.13083/1414-3984/reveng.v24n1p15-21

Corrêa, P. C.; Oliveira, G. H. H. de; Santos, E. de S. Thermodynamic properties of agricultural products processes. In: Arana, I. (ed.). Physical properties of foods: Novel measurement techniques and applications. Boca Raton: CRC Press, 2012. Chap.6, p.131-141. https://doi.org/10.1201/b11542-7

Corrêa, P. C.; Reis, M. F. T.; Oliveira, G. H. H. de; Oliveira, A. P. L. R. de; Botelho, F. M. Moisture desorption isotherms of cucumber seeds: modeling and thermodynamic properties. Journal of Seed Science, v.37, p.218-225, 2015. https://doi.org/10.1590/2317$1545 \mathrm{v} 37 \mathrm{n} 3149549$ 
Draper, N. R.; Smith, H. Applied regression analysis. 3.ed. New York: John Wiley \& Sons, 1998. 736p. https://doi. org/10.1002/9781118625590

Ferreira, S. C. de S.; Silva, H. W. da; Rodovalho, R. S. Isotermas de dessorção e calor latente de vaporização da semente de pimenta Cumari Amarela (Capsicum chinense L.). Revista Liberato, v.13, p.1-16, 2011.

Goneli, A. L. D.; Corrêa, P. C; Oliveira, G. H. H. de; Gomes, C. F.; Botelho, F. M. Water sorption isotherms and thermodynamic properties of pearl millet grain. International Journal of Food Science and Technology, v.45, p.282-383, 2010. https://doi. org/10.1111/j.1365-2621.2010.02208.x

Goneli, A. L. D.; Corrêa, P. C.; Oliveira, G. H. H. de; Oliveira, A. P. L. R. de; Orlando, R. C. Moisture sorption isotherms of castor beans. Part 2: Termodynamic properties. Revista Brasileira de Engenharia Agrícola e Ambiental, v.20, p.757-762, 2016a. https:// doi.org/10.1590/1807-1929/agriambi.v20n8p757-762

Goneli, A. L. D.; Corrêa, P. C.; Oliveira, G. H. H. de; Resende, O.; Mauad, M. Moisture sorption isotherms of castor beans. Part 1: Mathematical modeling and hysteresis. Revista Brasileira de Engenharia Agrícola e Ambiental, v.20, p.751-756, 2016b. https:// doi.org/10.1590/1807-1929/agriambi.v20n8p751-756

Henderson, S. M. A basic concept of equilibrium moisture content. Agricultural Engineering, v.33, p29-31, 1952.

Krug, R. R.; Hunter, W. G.; Grieger, R. A. Enthalpy-entropy compensation: 1 - Some fundamental statistical problems associated with the analysis of van't Hoff and Arrhenius data. Journal of Physical Chemistry, v.80, p.2335-2341, 1976a. https:// doi.org/10.1021/j100562a006

Krug, R. R.; Hunter, W. G.; Grieger, R. A. Enthalpy-entropy compensation: 2 - Separation of the chemical from the statistical effect. Journal of Physical Chemistry, v.80, p.2341-2351, $1976 \mathrm{~b}$. https://doi.org/10.1021/j100562a007

Leffler, J. E. The enthalpy-entropy relationship and its implications for organic chemistry. The Journal of Organic Chemistry, v.20, p.1202-1231, 1955. https://doi.org/10.1021/jo01126a009
Ribeiro, J. A.; Oliveira, D. T.; Passos, M. L.; Barrozo, M. A. S. The use of nonlinearity measures to discriminate the equilibrium moisture equations for Bixa orellana seeds. Journal of Food Engineering, v.66, p.63-68, 2005. https://doi.org/10.1016/j.jfoodeng.2004.02.040

Rockland, L. B.; Stewart, G. F. Water activity: Influences on food quality. 1. ed. New York: Academic Press, 1981. 95

Rodovalho, R. S.; Silva, I. L.; Silva, H. W. da; Rossetto, C. A. V. Isotermas de sorção dos grãos de pimenta bode. Revista Agrotecnologia, v.6, p.80-101, 2015. https://doi.org/10.12971/2179-5959/ agrotecnologia.v6n1p80-101

Silva, C. L. O. C. e; Faria, L. J. G. de; Costa, C. M. L. Comportamento higroscópico de partes aéreas de pimenta-de-macaco (Piper aduncum L.). Revista Brasileira de Engenharia Agrícola e Ambiental, v.19, p.376-381, 2015a. https://doi.org/10.1590/18071929/agriambi.v19n4p376-381

Silva, H. W. da; Costa, L. M.; Resende, O.; Oliveira, D. E. C. de; Soares, R. S.; Vale, L. S. R. Higroscopicidade das sementes de pimenta (Capsicum chinense L.) Revista Brasileira de Engenharia Agrícola e Ambiental, v.19, p.780-784, 2015b. https://doi.org/10.1590/18071929/agriambi.v19n8p780-784

Silva, H. W. da; Costa, L. M.; Resende, O.; Oliveira, D. E. C. de; Soares, R. S.; Vale, L. S. Thermodynamic properties of pepper seeds Variety 'Cabacinha'. Científica, v.44, p.14-22, 2016. https://doi. org/10.15361/1984-5529.2016v44n1p14-22

Silva, H. W. da; Rodovalho, R. S. Adsorption isotherms and vaporization latent heat of malagueta pepper seeds. Científica, v.44, p.5-13, 2016. https://doi.org/10.15361/1984-5529.2016v44n1p5-13

Sousa, K. A.; Resende, O.; Goneli, A. L. D.; Smaniotto, T. A. de S.; Oliveira, D. E. C. de. Thermodynamic properties of water desorption of forage turnip seeds. Acta Scientiarum. Agronomy, v.37, p.11-19, 2015. https://doi.org/10.4025/actasciagron.v37i1.19333

Thompson, T. L.; Peart, R. M.; Foster, G.H. Mathematical simulation of corn drying-a new model. Thansactions of the ASAE, v.11, p.582-586, 1968. https://doi.org/10.13031/2013.39473

Zeymer, J. S.; Corrêa, P. C.; Oliveira, G. H. H. de; Baptestini, F. M.; Freitas, R. C. P. Desorption isotherms of Lactuca sativa seeds. Revista Brasileira de Engenharia Agrícola e Ambiental, v.21, p.568-572, 2017. https://doi.org/10.1590/1807-1929/agriambi.v21n8p568-572 